\title{
INTENSI SEKSUAL REMAJA: APA SAJA FAKTOR PEMBEDANYA?
}

\author{
Rahmi Lubis ${ }^{1}$, Zahrotur Rusyda Hinduan², Ratna Jatnika ${ }^{3}$, dan Hendriati Agustiani ${ }^{4}$ \\ ${ }^{1}$ Fakultas Psikologi, Universitas Medan Area \\ Jalan Kolam No. 1, Medan, 20223 \\ ${ }^{1,2,3,4}$ Fakultas Psikologi, Universitas Padjadjaran \\ Jalan Raya Bandung-Sumedang KM 21 Jatinangor, Sumedang, 45363 \\ Email: makmunrahmi@yahoo.com
}

\begin{abstract}
ABSTRAK
Perilaku seksual dini menimbulkan dampak yang merugikan bagi remaja. Perilaku seksual remaja dapat diprediksi melalui intensi seksual. Salah satu faktor yang mempengaruhi intensi seksual remaja adalah keyakinan mengenai hubungan seksual yang bersumber dari pengetahuan, pengalaman, dan ketersediaan sarana di lingkungan. Namun, beberapa penelitian menunjukkan hasil yang tidak konsisten mengenai faktor-faktor yang mempengaruhi intensi seksual remaja dan membutuhkan penyelidikan lebih lanjut. Penelitian ini bertujuan untuk menguji faktor demografi dan perilaku yang membentuk intensi seksual pada 1,006 siswa SMA di Medan. Penelitian ini menggunakan Skala Intensi Seksual Remaja Indonesia untuk mengukur intensi seksual remaja dan uji beda nonparametrik Kruskall-Wallis dan Mann Whitney U sebagai teknik analisis data. Hasil penelitian menunjukkan bahwa usia, jenis kelamin, pengalaman seks pertama, pengalaman seksual, status hubungan romantis, dan sumber informasi seksual menyebabkan perbedaan intensi seksual. Hasil penelitian ini bermanfaat untuk menyusun program pencegahan dan penanganan masalah hubungan seksual dini yang diarahkan pada pemberian edukasi seksual sedini mungkin, pelibatan teman sebaya dan media dalam komunikasi seksual yang sehat, serta penguatan fungsi pengawasan orang tua.
\end{abstract}

Kata kunci: demografi; intensi seksual; Indonesia; perilaku seksual, remaja

\section{ADOLESCENT SEXUAL INTENTIONS: WHAT ARE THE DIFFERENTIATING FACTORS?}

\begin{abstract}
Early sexual behavior has negative consequences for adolescents' health. Sexual intention, which is the best predictor of sexual behavior, comes from their sexual beliefs formed by knowledge, experience, and resource availability. However, several studies have shown inconsistent data regarding predictors of adolescents sexual intention and it needs further investigation. This study examines the demographic and behavioral factors that shape sexual intentions in 1,006 high school students in Medan. The study used The Indonesian Youth Sexual Intention Scale to measure sexual intention and Kruskal-Wallis and Mann Whitney U non-parametric test as data analysis techniques. The results showed that age, gender, first sex experience, sexual experience, romantic relationship status, and sources of sexual information caused differences in sexual intentions. The results are beneficial for developing prevention dan intervention programs for early sexual intercourse problems on providing sexual education as early as possible, involving peers and the media in healthy sexual communication, and strengthening parental monitoring.
\end{abstract}

Keywords: adolescent; demographic; Indonesia; sexual behavior; sexual intention 


\section{PENDAHULUAN}

Masuknya usia remaja ditandai dengan aktifnya hormon seksual yang menimbulkan ketertarikan dengan lawan jenis dan munculnya dorongan seksual. Perilaku seksual diekspresikan dengan cara yang bervariasi, mulai dari sexual abstinence, fantasi seksual, flirting, menyentuh, berpelukan, berciuman, hingga tindakan yang melibatkan alat kelamin seperti oral sex, anal sex, dan vaginal sex (Fortenberry, 2013). Di antara jenis perilaku seksual yang disebutkan di atas, vaginal sex merupakan perilaku seksual yang menimbulkan risiko paling merugikan bagi remaja. Risiko yang utama adalah kehamilan tidak diinginkan dan terinfeksi penyakit menular seksual (Nigussie dkk., 2020). Selain itu, terdapat pula risiko prestasi akademis yang rendah (Lanari dkk., 2020), perilaku seksual berisiko, dan penyalahgunaan zat dan perilaku antisosial saat usia dewasa (Prendergast dkk., 2019). Simtom depresi, simtom fisik, ketidakbahagiaan, kesepian, kesedihan, dan mood mudah berubah (Donahue dkk., 2013; Madkour dkk., 2010) juga ditunjukkan di usia dewasa jika remaja lebih cepat aktif secara seksual.

Masyarakat Indonesia merupakan masyarakat religius yang menganggap hubungan seks sebagai hal yang bersifat pribadi, tabu untuk diekspresikan secara terbuka, dan hanya boleh dilakukan dalam pernikahan (Rigo \& Saroglou, 2018). Sosialisasi seksual dalam keluarga dan masyarakat diarahkan pada upaya mencegah hubungan seksual di luar pernikahan. Masyarakat mengembangkan konsepsi mengenai keperawanan dan memberi hukuman publik bagi orang yang melanggar guna mencegah hubungan seks di luar nikah. Di sisi lain, hubungan romantis antarlawan jenis diperbolehkan sehingga remaja menghadapi konflik dalam pemenuhan hasrat seksualnya.

Di satu sisi, remaja terdorong menunjukkan perilaku seksual sebagai konsekuensi dari interaksi yang intens dengan lawan jenis. Di sisi lain, remaja akan mendapatkan sanksi sosial yang menimbulkan rasa malu jika ia diketahui melakukan hubungan seksual. Nilai-nilai yang diinternalisasikan oleh lingkungan membentuk rasa jijik pada diri remaja terhadap aktivitas seksual. Rasa malu dan jijik terhadap hubungan seksual di luar nikah membuat remaja menyembunyikan aktivitas seksualnya. Hubungan seksual, apalagi jika mengakibatkan kehamilan di luar nikah, mendapatkan penolakan keras dari masyarakat. Namun, masyarakat dapat menerima hubungan seksual atau kehamilan pada pasangan yang akan segera menikah (Shaluhiyah, 2007). Adanya ambivalensi sikap seksual ini menjadi ciri dari kelompok masyarakat semi-restrictive seperti Indonesia. Ambivalensi ini membuat larangan melakukan hubungan seks di luar nikah menjadi tidak mudah untuk ditegakkan (Susanto dkk., 2016).

Penelitian yang dilakukan di 23 provinsi di Indonesia pada tahun 2015 menunjukkan bahwa 58.2\% remaja usia 15 - 19 tahun telah melakukan hubungan seksual (Oktriyanto \& Alfiasari, 2019). Penelitian lain menemukan siswa SMA yang sudah terlibat dalam hubungan seksual mencapai $7.7 \%$ pada tahun 2012 dan 9\% di tahun 2018 (Bauer, 2015; Sari \& Rokhanawati, 2018). Secara lebih spesifik, riset tahun 2019 di Medan menunjukkan bahwa 6.5\% hingga 7.9\% remaja telah melakukan hubungan seksual (Fatoni \& Situmorang, 2020; Sanusi \& Arde M., 2019). Medan sebagai kota metropolitan terbesar ketiga di Indonesia, merupakan pusat kegiatan ekonomi dan hiburan di Sumatera Utara. Hal ini berdampak pada maraknya aktivitas pelacuran anak di bawah umur (Efendi, 2018) dan prostitusi remaja online (Dinamika Rakyat, 2017). Data penyebaran HIV tahun 2019 menempatkan Sumatera Utara sebagai urutan kelima terbanyak (2,463 kasus) di Indonesia (Khairani, 2020) dan Medan sebagai kota dengan kasus HIV paling tinggi di Sumatera Utara (National AIDS Commission Secretary, 2012).

Masalah hubungan seksual dini pada remaja dapat diatasi dengan mengenali faktor penyebabnya. Perilaku seksual dapat diprediksi melalui sejumlah faktor yang mempengaruhinya. Theory of Planned Behavior (TPB) menyebutkan bahwa prediktor terkuat dari perilaku adalah intensi. Menurut Ajzen (2005), intensi adalah niat atau kesiapan individu untuk menunjukkan perilaku tertentu. Intensi dibentuk oleh kumpulan keyakinan (beliefs) yang tersimpan dalam memori individu. Keyakinan tersebut terbentuk oleh faktor personal seperti usia, jenis kelamin, pendidikan, penghasilan, karakter pribadi, kecerdasan, sistem nilai, stereotip, pengetahuan, serta pengalaman; dan faktor sosial yang meliputi norma lingkungan, ekonomi, geografi, media, serta intervensi (Ajzen, 2019). Dapat dikatakan, intensi seksual dapat dibentuk oleh faktor demografi dan perilaku yang dapat memberikan pengetahuan serta pengalaman mengenai hubungan seksual bagi remaja.

Faktor demografi dapat meliputi usia, jenis kelamin, etnis, agama, penghasilan orang tua, dan pendidikan orang tua. Terkait faktor demografi, literatur menunjukkan bahwa usia, jenis kelamin, tingkat 
pendidikan orang tua, kelompok etnis dan agama, serta status sosial ekonomi keluarga memengaruhi intensi seksual remaja (Olaoye \& Agbede, 2019; Cueto \& Leon, 2016; Manaf dkk., 2014; Bengesai dkk., 2018). Bertolak belakang dengan faktor itu, penelitian lain menemukan bahwa kelompok etnis dan agama, usia, status sosial ekonomi keluarga, dan tingkat pendidikan orangtua tidak membedakan perilaku seksual remaja (Wong, 2012; AS dkk., 2014; Shek, 2013; Akers dkk., 2016). Peltzer \& Pengpid (2016) menyebutkan bahwa pria memiliki intensi seksual lebih tinggi sedangkan Santeli. dkk. (2015) menemukan hal yang sebaliknya. Sementara itu, Lyons dkk. (2015) menemukan bahwa jenis kelamin tidak membedakan perilaku seksual remaja.

Di samping faktor demografi, faktor perilaku yang mendorong intensi seksual remaja dapat berupa pengalaman seks pertama, status romantis, perilaku seksual sebelumnya, dan sumber informasi seksual yang diakses. Hasil penelitian menunjukkan bahwa besarnya perbedaan usia subjek dan usia pasangannya saat melakukan seks pertama (Oudekerk dkk., 2014) membedakan intensi seksual remaja. Namun, Yaya \& Bishwajit (2018); Gräf dkk. (2020), dan Senn \& Carey (2011) menemukan bahwa usia subjek dan usia pasangan saat seks pertama hanya membedakan perilaku seks berisiko remaja di masa yang akan datang. Status hubungan romantis disebutkan oleh Lin dkk. (2019) membedakan intensi seksual remaja, tetapi Abdullah dkk. (2020) menemukan hal yang sebaliknya. Landry dkk. (2017) dan Lee \& Park (2020) menyatakan bahwa sumber informasi seksual yang diakses remaja membedakan intensi seksual. Namun, hal sebaliknya dinyatakan oleh Putri dkk. (2021), yaitu tidak ada perbedaan jenis sumber informasi yang diakses remaja yang memiliki intensi seksual tinggi maupun rendah. Penelitian lain menunjukkan bahwa sumber informasi seksual yang paling banyak diakses adalah orang tua (Eversole dkk., 2016). Akan tetapi, temuan dari Putri dkk. (2021) menemukan media dan teman adalah sumber yang paling banyak diakses. Informasi seksual dari guru tidak membedakan intensi seksual, sedangkan informasi dari orangtua, teman, dan media dapat membedakan intensi seksual (Bleakley dkk., 2009). Berdasarkan penjelasan di atas, dapat dinyatakan bahwa peran faktor-faktor tersebut terhadap intensi seksual masih belum dapat disimpulkan sehingga dinilai perlu untuk mengkaji faktor-faktor demografi dan perilaku apa saja yang mempengaruhi perbeedaan intensi seksual remaja.

\section{METODE}

Penelitian ini dilakukan menggunakan pendekatan kuantitatif komparatif dengan metode survei. Penelitian ini bertujuan untuk menguji perbedaan intensi seksual berdasarkan variabel demografi yang telah ditentukan. Sebanyak 1,006 siswa berusia 15 s.d. 18 tahun di Kota Medan dipilih secara cluster randomization yang berasal dari tiga belas SMA di empat kecamatan di Medan. Pengambilan data dilakukan dari bulan Januari hingga Februari 2020 setelah mendapatkan persetujuan etik dari Komisi Etik Penelitian Universitas Padjadjaran. Guru dan siswa membaca dan menandatangani informed consent sebelum pengambilan data dilakukan. Variabel utama penelitian ini adalah intensi seksual. Variabel ini diukur dengan Skala Intensi Seksual Remaja Indonesia yang disusun oleh peneliti (Lubis dkk., 2020), dengan mengambil item intensi seksual (tiga item). Skala berbentuk Likert dengan tujuh pilihan jawaban, bergerak dari nilai 1 hingga 7 menggunakan pilihan jawaban antara sangat tidak setuju (skor 1) hingga sangat setuju (skor 7). Skala ini menunjukkan validitas isi yang memadai $(\mathrm{CVI}=.93$ ) dan memiliki tingkat fitness yang baik (Chi-square $=819.420 ; \mathrm{p}=.000$; RMSEA $=.056$; CFI $=.0978$; TLI $=.0972$ ). Uji reliabilitas dengan Cronbach Alpha menunjukkan koefisien sebesar .911. Dengan demikian, skala ini dinilai valid dan reliabel untuk mengukur intensi seksual remaja.

Variabel bebas yang diteliti dalam penelitian ini adalah faktor demografi dan perilaku. Faktor demografi antara lain usia, agama, etnis, jenis kelamin, status sosial ekonomi, tingkat pendidikan ayah, dan tingkat pendidikan ibu. Semua faktor demografi ini merupakan isian yang harus dituliskan jawabannya. Status sosial ekonomi dihitung dengan membagi jumlah pendapatan ayah dan ibu dengan jumlah tanggungan orang tua. Hasil perhitungan dikategorikan menjadi empat kelompok, yaitu sangat rendah $(<717,770$ rupiah), rendah (717,770 s.d. 1,400,000 rupiah), menengah $(1,403,261$ s.d. 2,778,000 rupiah), dan tinggi (> 2,778,000 rupiah) berdasarkan data dari BPS Kota Medan (2020). Adapun faktor perilaku yang diukur meliputi pengalaman seks pertama (usia seks pertama, usia pasangan seks pertama, status pasangan seks pertama, tempat seks pertama), status hubungan romantis, pengalaman seksual 
(perilaku seksual, hubungan seksual bulan lalu, penggunaan kondom, masturbasi), dan sumber informasi seksual. Usia seks pertama, tempat seks pertama, dan sumber informasi seksual merupakan isian yang harus dituliskan jawabannya. Item status pasangan seks pertama terdiri dari dua pilihan, yaitu pacar dan bukan pacar. Status hubungan romantis dengan tiga pilihan, yaitu sedang pacaran, sedang tidak pacaran, dan tidak pernah pacaran. Pengalaman seksual terdapat empat pilihan, yaitu tidak pernah, 1 kali, 2-3 kali, dan $>3$ kali. Terakhir, item masturbasi merupakan item dengan pilihan iya atau tidak. Pengolahan data menggunakan analisis uji beda nonparametrik Kruskall-Wallis dan Mann Whitney U dengan bantuan software statistik SPSS versi 24 for Mac.

\section{HASIL DAN PEMBAHASAN}

Subjek berusia 15 s.d. 18 tahun $(M=16.02, S D=.8660)$ dan sebagian besar bersekolah di SMA Negeri. Mayoritas subjek adalah perempuan, beragama Islam, dan beretnis Batak. Sebagian besar memiliki orangtua yang berpendidikan sekolah menengah dan tingkat sosial ekonomi sangat rendah. Data yang lebih lengkap mengenai demografi umum respoden penelitian dapat dilihat pada Tabel 1.

Tabel 1. Gambaran Demografi Responden Penelitian

\begin{tabular}{|c|c|c|}
\hline Demografi & $\mathbf{n}$ & $\%$ \\
\hline \multicolumn{3}{|l|}{ Jenis kelamin } \\
\hline Laki-laki & 471 & 46.82 \\
\hline Perempuan & 535 & 53.18 \\
\hline \multicolumn{3}{|l|}{ Usia } \\
\hline 15 tahun & 321 & 31.9 \\
\hline 16 tahun & 389 & 38.7 \\
\hline 17 tahun & 250 & 24.8 \\
\hline 18 tahun & 46 & 4.6 \\
\hline \multicolumn{3}{|l|}{ Etnis } \\
\hline Batak & 531 & 52.8 \\
\hline Jawa & 210 & 20.8 \\
\hline Minang & 151 & 15 \\
\hline Melayu & 47 & 4.7 \\
\hline Aceh & 23 & 2.3 \\
\hline Lain- lain & 44 & 4.4 \\
\hline \multicolumn{3}{|l|}{ Agama } \\
\hline Islam & 634 & 63 \\
\hline Kristen & 332 & 33 \\
\hline Katolik & 33 & 3.1 \\
\hline Hindu & 7 & .90 \\
\hline \multicolumn{3}{|l|}{ Pendidikan Ayah } \\
\hline SD & 40 & 3.97 \\
\hline SMP & 84 & 8.36 \\
\hline SMA sederajat & 520 & 51.68 \\
\hline Diploma & 40 & 3.98 \\
\hline Perguruan Tinggi & 251 & 24.96 \\
\hline Tidak dijawab & 71 & 7.05 \\
\hline \multicolumn{3}{|l|}{ Pendidikan Ibu } \\
\hline SD & 59 & 5.86 \\
\hline SMP & 87 & 8.65 \\
\hline SMA sederajat & 541 & 53.78 \\
\hline Diploma & 74 & 7.36 \\
\hline Perguruan Tinggi & 187 & 18.59 \\
\hline Tidak dijawab & 58 & 5.76 \\
\hline
\end{tabular}




\begin{tabular}{lll}
\hline Tingkat Sosial Ekonomi & & \\
Sangat Rendah & 415 & 41.26 \\
Rendah & 232 & 23.06 \\
Menengah & 129 & 12.82 \\
Tinggi & 58 & 5.76 \\
Tidak dijawab & 172 & 17.10 \\
\hline Asal Sekolah & & \\
Swasta & 412 & 40.95 \\
Negeri & 594 & 59.05 \\
\hline
\end{tabular}

Ditinjau dari perilaku seksual, sebagian besar responden sedang tidak memiliki hubungan romantis (77\%), tidak pernah masturbasi (70\%), belum pernah berhubungan kelamin (89\%), dan tidak melakukan hubungan kelamin sebulan terakhir $(96 \%)$. Data menunjukkan bahwa terdapat $11 \%$ responden yang sudah melakukan hubungan kelamin, dengan usia pertama kali berhubungan seks adalah 16 tahun, dilakukan dengan pacar yang berusia sama, di tempat tinggal responden sendiri. Terdapat 43 responden yang melakukan hubungan kelamin sebulan terakhir, dan hanya lima belas responden yang menggunakan kontrasepsi (kondom). Sumber informasi seksual terbanyak yang diakses adalah dari teman sebaya dan media. Secara lebih rinci, data perilaku seksual responden disajikan dalam Tabel 2.

Tabel 2. Gambaran Perilaku Seksual Responden

\begin{tabular}{|c|c|c|}
\hline $\begin{array}{r}\text { Perilaku Seksual } \\
\end{array}$ & $\mathbf{n}$ & $\%$ \\
\hline \multicolumn{3}{|l|}{ Status Hubungan Romantis } \\
\hline Tidak pernah pacaran & 319 & 31.7 \\
\hline Sedang tidak pacaran & 453 & 45 \\
\hline Sedang punya pacar & 233 & 23.2 \\
\hline Tidak menjawab & 1 & .10 \\
\hline \multicolumn{3}{|l|}{ Perilaku Masturbasi } \\
\hline Tidak & 706 & 70.18 \\
\hline Iya & 299 & 29.72 \\
\hline Tidak menjawab & 1 & .10 \\
\hline \multicolumn{3}{|l|}{ Hubungan Kelamin } \\
\hline Belum pernah memikirkan & 481 & 47.82 \\
\hline Pernah memikirkan & 411 & 40.85 \\
\hline 1 kali & 86 & 8.55 \\
\hline 2- 3 kali & 14 & 1.39 \\
\hline$>3$ kali & 13 & 1.29 \\
\hline Tidak menjawab & 1 & .10 \\
\hline \multicolumn{3}{|l|}{ Usia Seks Pertama } \\
\hline$<15$ tahun & 15 & 1.49 \\
\hline 15 tahun & 36 & 3.58 \\
\hline 16 tahun & 42 & 4.17 \\
\hline 17 tahun & 20 & 1.99 \\
\hline 18 tahun & 5 & .50 \\
\hline Tidak pernah & 887 & 88.17 \\
\hline Tidak menjawab & 1 & .10 \\
\hline \multicolumn{3}{|l|}{ Usia Pasangan di Seks Pertama } \\
\hline$<15$ tahun & 18 & 1.78 \\
\hline 15 tahun & 22 & 2.18 \\
\hline 16 tahun & 32 & 3.17 \\
\hline 17 tahun & 30 & 2.98 \\
\hline 18 tahun & 10 & 1 \\
\hline$>18$ tahun & 5 & .50 \\
\hline
\end{tabular}




\begin{tabular}{|c|c|c|}
\hline $\begin{array}{l}\text { Tidak pernah } \\
\text { Tidak menjawab }\end{array}$ & $\begin{array}{l}887 \\
2\end{array}$ & $\begin{array}{l}88.17 \\
.20\end{array}$ \\
\hline \multicolumn{3}{|c|}{ Status Pasangan di Seks Pertama } \\
\hline Tidak & 887 & 88.17 \\
\hline Bukan pacar & 35 & 3.48 \\
\hline Pacar & 81 & 8.13 \\
\hline Tidak menjawab & 2 & .22 \\
\hline \multicolumn{3}{|l|}{ Tempat Seks Pertama } \\
\hline Tempat tinggal sendiri & 49 & 4.87 \\
\hline Tempat tinggal orang lain & 19 & 1.88 \\
\hline Tempat hiburan & 38 & 3.78 \\
\hline Tempat umum & 11 & 1.1 \\
\hline Tidak pernah & 887 & 88.17 \\
\hline Tidak menjawab & 2 & .20 \\
\hline Perilaku Seksual & $\mathbf{n}$ & $\%$ \\
\hline \multicolumn{3}{|c|}{ Hubungan Kelamin di Sebulan Terakhir } \\
\hline Tidak pernah & 963 & 95.72 \\
\hline $1 \mathrm{kali}^{1}$ & 29 & 2.88 \\
\hline 2-3 kali & 8 & .80 \\
\hline$>3$ kali & 5 & .50 \\
\hline Tidak menjawab & 1 & .10 \\
\hline \multicolumn{3}{|c|}{ Penggunaan Kondom 1 bulan Terakhir } \\
\hline Tidak pernah & 990 & 98.41 \\
\hline 1 kali & 11 & 1.09 \\
\hline 2-3 kali & 2 & .20 \\
\hline$>3$ kali & 2 & .20 \\
\hline Tidak menjawab & 1 & .10 \\
\hline \multicolumn{3}{|l|}{ Sumber Informasi Seksual } \\
\hline Orangtua, guru & 77 & 7.66 \\
\hline Orangtua, guru, teman & 27 & 2.68 \\
\hline Orangtua, guru, media & 195 & 19.38 \\
\hline Teman, media & 362 & 35.98 \\
\hline Media & 308 & 30.62 \\
\hline Tidak menjawab & 37 & 3.68 \\
\hline
\end{tabular}

Analisis data menggunakan uji beda nonparametrik Kruskal-Wallis dan Mann Whitney $U$ dilakukan untuk menguji perbedaan intensi seksual berdasarkan kelompok usia, agama, etnis, tingkat pendidikan ayah, tingkat pendidikan ibu, usia seks pertama, usia pasangan seks pertama, status pasangan seks pertama, tempat seks pertama, jenis kelamin, status sosial ekonomi, status hubungan romantis, hubungan seksual selama ini, pengalaman seksual satu bulan terakhir, penggunaan kondom, perilaku masturbasi, dan sumber informasi seksual. Hasil analisis selengkapnya dapat dilihat pada Tabel 3.

Tabel 3. Hasil Ujibeda Faktor Demografi dan Perilaku

\begin{tabular}{llll}
\hline Variabel & Koefisien & Nilai $\mathrm{p}$ & Kesimpulan \\
\hline Demografi & & & \\
\hline Agama & $\chi^{2}(3)=.513$ & .916 & Tidak signifikan \\
Etnis & $\chi^{2}(5)=4.818$ & .435 & Tidak signifikan \\
Usia & $\chi^{2}(3)=9.347$ & .025 & Signifikan \\
Jenis kelamin & $\mathrm{U}=75.686$ & $<.001$ & Signifikan \\
& $(\mathrm{Np}=471 ; \mathrm{Nw}=535)$ & & \\
Status SOSEK & $\chi^{2}(3)=.567$ & .904 & Tidak Signifikan \\
Pendidikan Ayah & $\chi^{2}(4)=7.506$ & .111 & Tidak Signifikan
\end{tabular}




\begin{tabular}{llll} 
Pendidikan Ibu & $\chi^{2}(4)=4.246$ & .374 & Tidak Signifikan \\
\hline Perilaku & & & \\
\hline Pengalaman seks pertama & & & \\
Usia & $\chi^{2}(5)=137.972$ & .000 & Signifikan \\
$\begin{array}{l}\text { Status partner } \\
\text { Usia partner }\end{array}$ & $\chi^{2}(2)=1.642$ & .234 & Tidak Signifikan \\
Tempat & $\chi^{2}(6)=7.790$ & .143 & $\begin{array}{l}\text { Tidak Signifikan } \\
\text { Signifikan }\end{array}$ \\
\hline Perilaku & $\chi^{2}(4)=144.552$ & .000 & \\
\hline $\begin{array}{l}\text { Hubungan seks selama } \\
\text { ini }\end{array}$ & Koefisien & Nilai p & Kesimpulan \\
$\begin{array}{l}\text { Hubungan seks bulan lalu } \\
\text { Kontrasepsi bulan lalu }\end{array}$ & $\chi^{2}(3)=63.623$ & .000 & Signifikan \\
Masturbasi & $\chi^{2}(3)=35.970$ & .000 & Signifikan \\
& $\mathrm{U}=142,977.500$ & .000 & Signifikan \\
Status romantis & $(\mathrm{Ny}=299 ; \mathrm{Nt}=706)$ & .000 & Signifikan \\
Sumber informasi seksual & $\chi^{2}(2)=20.625$ & .000 & Signifikan \\
\hline
\end{tabular}

Dari Tabel 3 dapat disimpulkan bahwa usia saat ini, jenis kelamin, usia melakukan seks pertama, tempat melakukan seks pertama, pengalaman seksual, status hubungan romantis, dan informasi seksual menghasilkan perbedaan intensi seksual. Adapun agama, etnis, status sosial ekonomi, tingkat pendidikan orangtua, usia pasangan seks pertama, dan status pasangan saat seks pertama tidak menghasilkan perbedaan intensi seksual.

\section{PEMBAHASAN}

Hasil analisis uji beda menunjukkan bahwa usia subjek menyebabkan perbedaan intensi seksual. Usia 18 tahun menunjukkan perbedaan intensi seksual yang signifikan dan lebih tinggi dibandingkan dengan usia 15 dan 16 tahun. Hal ini sejalan dengan hasil penelitian yang menemukan bahwa semakin tua usia, semakin tinggi intensi seksual yang dimiliki (Salih dkk., 2015). Usia saat melakukan seks pertama juga membedakan intensi seksual, yakni usia 17 tahun memiliki intensi tertinggi dan berbeda secara signifikan dengan usia 15 dan 18 tahun. Usia 17 tidak berbeda dengan usia 16 tahun yang merupakan usia dengan intensi tertinggi dan merupakan usia rata-rata subjek saat ini.

Intensi seksual laki-laki lebih tinggi dan berbeda secara signifikan dengan perempuan. Hal ini sesuai dengan penelitian yang menyebutkan pria lebih aktif secara seksual dibanding remaja perempuan di Nepal (Adhikari dkk., 2018) dan Taiwan (Lin dkk., 2019). Hasil penelitian lain menunjukkan bahwa pria cenderung lebih terbuka atau bahkan mengungkapkan secara berlebihan aktivitas seksualnya dibandingkan perempuan yang cenderung menutupi atau memperkecil jawaban mengenai perilaku seksualnya (Soler-Hampejsek dkk., 2013).

Remaja yang memiliki pengalaman seksual, tidak peduli jumlah frekuensinya, memiliki intensi seksual yang lebih tinggi dibandingkan remaja yang belum berpengalaman. Hal ini sesuai dengan pernyataan Ajzen (1991) bahwa pengalaman akan mempermudah subjek untuk melakukan tindakan tertentu. Pengalaman hubungan seksual sebelumnya meningkatkan kontrol perilaku (Turchik, 2011) dan intensi seksual (Lino dkk., 2014) sehingga menjadi prediktor penting bagi perilaku seksual berikutnya (Fu \& Juan, 2017). Sejalan dengan tersebut, Awaluddin dkk. (2015) menemukan bahwa remaja yang pernah melakukan masturbasi menunjukkan intensi seksual yang lebih tinggi dibandingkan dengan subjek yang tidak melakukan.

Subjek yang sedang memiliki pasangan menunjukkan intensi seksual yang lebih tinggi dibanding subjek yang tidak pernah atau sedang tidak memiliki pasangan saat ini. Keberadaan pasangan memperbesar peluang remaja melakukan aktivitas seksual, apalagi jika pasangan tersebut memiliki pengalaman seksual. Penelitian menunjukkan bahwa desakan dari pasangan memunculkan keinginan 
remaja untuk memenuhi permintaan tersebut sehingga terlibat dalam aktivitas seksual (Oudekerk dkk., 2014; Suleiman \& Deardorff, 2015).

Remaja yang mendapatkan informasi seksual dari guru dan teman menunjukkan intensi seksual yang lebih rendah dibandingkan remaja yang mengakses dari media atau internet. Remaja biasanya membagikan pengetahuan berdasarkan pengalaman seksualnya kepada temannya. Komunikasi seksual dengan teman menumbuhkan sexual self efficacy (Pariera, 2018) sekaligus sikap permisif terhadap hubungan seksual (Nogueira Avelar e Silva dkk., 2020), sehingga menimbulkan dorongan untuk melakukan hubungan seksual. Namun, adanya tambahan informasi dari guru yang berfokus pada penanaman nilai sosial dan agama yang melarang praktik perilaku seksual di luar nikah (Kinaro, 2013) membuat remaja memiliki referensi pembanding mengenai perilaku seksual. Ditambah lagi, guru biasanya memberikan informasi mengenai aspek fisiologis hubungan seksual, seperti proses reproduksi dan kehamilan (Litras dkk., 2015).

Sebaliknya, media sosial atau internet menyediakan informasi seksual secara vulgar berupa video mengenai aktivitas hubungan seksual. Video tersebut dibuat secara dramatis dan tidak realistis dengan tujuan membangkitkan fantasi seksual penonton (Lubis, 2018). Remaja menggunakan tayangan pornografi tersebut sebagai hiburan, memunculkan dorongan seksual, mempelajari cara berhubungan seksual, dan mengusir rasa bosan (Rothman dkk., 2015). Dengan demikian, intensi seksual remaja yang mendapatkan informasi seksual dari media menjadi lebih tinggi (Doornwaard dkk., 2015; Parkes dkk., 2013; Eversole dkk., 2016; Tolou-Shams dkk., 2018).

Perbedaan agama tidak menghasilkan perbedaan intensi seksual. Hal ini disebabkan oleh adanya larangan berhubungan seksual di luar pernikahan dari semua agama yang diakui di Indonesia. Perbedaan tingkat keyakinan, penghayatan, dan penerapan ajaran agama lebih mempengaruhi intensi seksual remaja dibandingkan jenis agama yang dipeluk (LeJeune dkk., 2013). Nilai-nilai yang dianut oleh kelompok etnis di Indonesia mengacu pada nilai yang sama, yaitu pandangan semi-restrictive yang mendorong individu untuk menghindari hubungan seksual di luar pernikahan (Steinberg, 2002). Tidak ada metode pendidikan atau komunikasi seksual yang khusus dimiliki oleh etnis tertentu yang membedakan perilaku seksual individu dari etnis yang lainnya.

Tingkat kesejahteraan keluarga atau sosial ekonomi juga tidak membedakan intensi seksual remaja. Remaja dengan tingkat ekonomi rendah memiliki intensi seksual yang tidak berbeda dengan remaja yang berasal dari ekonomi menengah ataupun tinggi. Hal ini berbeda dengan hasil penelitian Santelli dkk. (2015) yang menemukan perilaku seksual yang lebih tinggi pada remaja dengan status sosial ekonomi lebih rendah. Tingkat sosial ekonomi biasanya identik dengan tingkat pendidikan orang tua dan berkaitan dengan keterbukaan orang tua melakukan komunikasi seksual. Adapun pada subjek penelitian, ditemukan bahwa komunikasi seksual orang tua tidak berbeda pada kelompok remaja dengan tingkat sosial ekonomi yang berbeda.

Komunikasi seksual dari orang tua kepada remaja memengaruhi intensi seksual remaja (Okigbo dkk., 2015). Komunikasi seksual yang bersifat direktif namun disampaikan dengan sikap menghargai dan kasih sayang berkorelasi dengan rendahnya keterlibatan remaja dalam hubungan seksual (Overbeek dkk., 2018). Intensi seksual lebih disebabkan oleh informasi yang diterima, harapan atau desakan lingkungan, serta kemudahan untuk melakukannya dibandingkan kondisi ekonomi keluarga. Selain itu, dalam penelitian ini, data mengenai penghasilan orangtua hanya diperoleh dari jawaban subjek yang mengandung bias ingatan, pengetahuan, serta social desirability. Dengan demikian, data status sosial ekonomi yang digunakan bisa jadi tidak menggambarkan kondisi subjek yang sesungguhnya.

Berbeda dengan Zou dkk. (2021), penelitian ini menunjukkan bahwa tingkat pendidikan ayah dan ibu dalam penelitian ini tidak membedakan intensi seksual remaja. Hal ini sejalan dengan temuan Akers dkk. (2016) bahwa tingkat pendidikan orang tua tidak signifikan memengaruhi perilaku seks remaja. Tingkat pendidikan yang tinggi berkaitan dengan lebih tingginya kesadaran tentang pentingnya pendidikan seks pada anak. Namun, pada umumnya, orang tua di Indonesia merasa tidak nyaman sehingga tidak melakukan komunikasi seksual secara optimal kepada anak-anaknya, terlepas dari apa latar belakang pendidikan orang tua tersebut (Wanufika dkk., 2017). Dengan demikian, perbedaan tingkat pendidikan orang tua tidak menghasilkan perbedaan intensi seksual anak.

Usia pasangan dan status pasangan saat seks pertama juga terbukti tidak membedakan intensi seksual responden penelitian. Keberadaan pasangan dan pengalaman seksual pasangan lebih mempengaruhi remaja untuk terlibat melakukan seks pertama kali dibandingkan usia dan status 
hubungannya dengan responden (Amoateng \& Kalule-Sabiti, 2016). Pengalaman seksual yang dimiliki pasangan memperbesar peluang untuk terjadinya hubungan seks karena pengalaman pasangan cenderung akan mendorong dan mempermudah responden melakukannya (Heidi Ann Lyons, 2017).

Jika dilihat dari gambaran perilaku seksual responden penelitian, terlihat bahwa mayoritas subjek belum pernah melakukan hubungan seksual. Data menunjukkan bahwa terdapat $11 \%$ responden yang mengaku telah melakukan hubungan seks. Angka ini lebih besar dibandingkan hasil penelitian yang menunjukkan angka pada rentang 6.5\% hingga 9\% remaja yang telah aktif secara seksual (Fatoni \& Situmorang, 2020; Sylviana dkk., 2018; Sari \& Rokhanawati, 2018). Namun, hasil penelitian ini sejalan dengan penelitian Berliana dkk. (2018) yang menemukan 11\% remaja Indonesia telah berhubungan seksual.

Untuk subjek yang sudah melakukan hubungan seks, usia pertama kali berhubungan seks 16 tahun sesuai dengan penelitian O'Sullivan (2015). Hal ini menunjukkan bahwa usia SMA merupakan tahapan di mana subjek mulai aktif berinteraksi dengan lawan jenis sesuai dengan tugas perkembangan seksualnya (Agustiani, 2006). Remaja usia 15 s.d. 18 tahun diharapkan mampu menerima identitas seksualnya, berminat dalam interaksi dengan teman sebaya lawan jenis, serta menyeleksi teman untuk pendamping hidupnya (Pikunas dkk., 2014). Dengan tugas perkembangan itu, dapat dipahami jika remaja usia SMA lebih aktif melakukan aktivitas seksual dibandingkan tahap perkembangan sebelumnya.

Sebagian besar subjek melakukan seks pertama dengan pacar yang berusia sama di tempat tinggal responden sendiri, yang menunjukkan bahwa pasangan atau teman sebaya merupakan pihak yang paling mempengaruhi keterlibatan remaja dalam perilaku seksual pertama (Walsh dkk., 2010). Pilihan untuk melakukan seks pertama di tempat tinggal sendiri menunjukkan bahwa kurangnya pengawasan orang tua memberikan peluang yang besar bagi remaja untuk melakukan hubungan seks (Lara \& Abdo, 2016). Ditemukan pula bahwa responden yang melakukan seks pertama di tempat tinggal pasangan atau tempat hiburan memiliki intensi seksual yang lebih besar dibandingkan responden yang melakukannya di tempat tinggal sendiri. Hal ini menunjukkan bahwa semakin besar kebebasan yang dimiliki subjek dalam menyalurkan dorongan seksualnya, maka semakin besar pula niatnya untuk melakukan hubungan seks. Hal ini sesuai dengan pernyataan Ajzen dkk. (2019) bahwa perasaan mampu melakukan dan situasi lingkungan yang memungkinkan akan meningkatkan intensi individu untuk melakukan hubungan seksual.

Dari total subjek, terdapat 42 orang (4\%) subjek penelitian yang mengaku berhubungan seks sebulan terakhir dan hanya lima belas orang (29\%) subjek yang menggunakan kontrasepsi (kondom). Angka tersebut lebih tinggi daripada remaja Malaysia (19\%) dan lebih rendah dari remaja Italia (38\%) dalam penggunaan kondom (Farid dkk., 2014; Marino dkk., 2014). Hal ini menunjukkan bahwa sebagian besar subjek memiliki risiko penularan infeksi seksual yang lebih besar akibat perilaku seks yang tidak aman (Poudel dkk., 2011). Rendahnya penggunaan alat kontrasepsi ini berkaitan erat dengan rendahnya pengetahuan akan risiko hubungan seks (Rahmartani \& Adisasmita, 2019) serta sulitnya memperoleh kontrasepsi akibat nilai sosial yang menganggap seks sebagai hal yang tabu di tengah masyarakat (Mohammadi dkk., 2020).

Dilihat dari perilaku mengakses informasi seksual, ditemukan bahwa sumber informasi yang terbanyak diakses oleh responden adalah teman sebaya dan media (Patui dkk., 2018). Remaja memilih teman sebaya dan media sebagai sumber informasi utama karena teman sebaya cenderung mendengarkan pendapatnya. Adapun media banyak dipilih karena sarana tersebut dapat diakses kapan saja dan memberikan informasi apapun yang dibutuhkan. Remaja enggan membicarakan topik seksual dengan orang tua karena perasaan tabu, rasa malu, dan menilai orangtua kurang memiliki pengetahuan seksual (Mekonen dkk., 2018). Informasi seksual dari guru juga terbatas pada aspek biologis hubungan seksual dan tidak melibatkan dialog dua arah (Eisenberg dkk., 2013). Remaja juga merasa takut dianggap melakukan perilaku yang buruk jika membicarakan seks dengan orang tua atau guru (DKT Indonesia, 2019).

Kekuatan dari penelitian ini adalah memberikan informasi variabel demografi dan perilaku remaja yang mempengaruhi perbedaan intensi seksual remaja. Jumlah sampel penelitian ini tergolong besar dan menggunakan teknik probabilitas sehingga memberikan hasil penelitian yang representatif dari kondisi populasi siswa SMA berusia 15 s.d. 18 tahun di kota Medan. 
Adapun keterbatasan yang dimiliki oleh penelitian ini adalah pertama, subjek penelitian adalah siswa SMA berusia 15 s.d. 18 tahun di kota Medan. Hal ini menyebabkan hasil penelitian hanya dapat digeneralisasi pada populasi dengan karakteristik yang sama. Kedua, penelitian ini mengukur topik yang sensitif, yakni intensi dan pengalaman seksual, menggunakan self report sehingga mengandung kemungkinan adanya social desirability. Namun demikian, upaya pemberian instruksi individual, pengisian skala tanpa identitas, serta penyimpanan skala yang telah diisi ke dalam amplop tertutup oleh subjek, telah dilakukan untuk membangun kepercayaan subjek. Goldberg dkk. (2014) juga berpendapat bahwa penggunaan self report dalam mengungkap pengalaman seksual menunjukkan hasil yang konsisten. Ketiga, pengukuran pendidikan orang tua dan penghasilan orang tua hanya menggunakan perspektif subjek dan tidak didukung oleh data kependudukan yang lebih akurat. Keempat, penelitian ini merupakan penelitian cross-sectional yang bertujuan menjelaskan hubungan variabel dengan variabel lainnya. Penelitian yang dilakukan tidak memberi informasi mengenai hubungan kausalitas atau perubahan dari waktu ke waktu (temporal relationship).

\section{SIMPULAN}

Berdasarkan data penelitian, dapat disimpulkan bahwa usia saat ini, usia melakukan seks pertama, tempat melakukan seks pertama, jenis kelamin, pengalaman seksual, status hubungan romantis, dan informasi seksual menghasilkan perbedaan intensi seksual. Hasil penelitian ini bermanfaat untuk membantu konselor remaja maupun konselor kesehatan reproduksi untuk menangani masalah perilaku seksual remaja. Temuan yang diperoleh dapat dikembangkan sebagai dasar program prevensi perilaku seksual dini remaja melalui pendidikan seksual yang tepat waktu dan metode yang dialogis, meningkatkan keterlibatan teman sebaya dan penggunaan media dalam komunikasi seksual yang sehat, meningkatkan efektivitas pengawasan orangtua terhadap aktivitas dan pergaulan anak-anaknya, serta memberi perlakuan yang sesuai dengan kebutuhan gender dalam menangani perilaku seksual remaja. Intervensi pada remaja yang telah aktif melakukan hubungan seksual dapat pula dikembangkan melalui edukasi seksual yang berfokus pada upaya second abstinence (membebaskan diri kembali dari hubungan seksual), mendorong penggunaan media yang sehat dan produktif, melakukan orientasi nilai dan tujuan hidup,mengeksplorasi bakat dan minat yang meningkatkan kepuasan psikologis, mengarahkan energi pada kegiatan yang meningkatkan life skills, serta peningkatan kompetensi orang tua dalam memberikan dukungan dan pengawasan yang seimbang. Penelitian eksperimen atau longitudinal perlu dilakukan untuk memperoleh informasi mengenai hubungan kausalitas atau perubahan dari waktu ke waktu (temporal relationship) antara intensi seksual dan prediktornya. Penelitian terhadap remaja dengan karakteristik berbeda juga perlu dilakukan untuk mendapatkan pemahaman yang lebih komprehensif mengenai faktor-faktor demografis yang mempengaruhi intensi seksual.

\section{UCAPAN TERIMA KASIH}

Ucapan terima kasih penulis sampaikan kepada kepala sekolah SMA dan guru, seluruh siswa yang berpartisipasi dalam penelitian ini, seluruh asisten penelitian, serta RistekDikti sebagai pemberi beasiswa BPPDN.

\section{DAFTAR PUSTAKA}

Abdullah, F., Rahman, N. A. A., Muhammad, N. A., Zainuddin, N. A., \& Samsudin, S. (2020). Association between social-cognitive factors and intention towards sexual activity among schoolgoing late adolescents in Kuantan, Malaysia. International Journal of Adolescence and Youth. https://doi.org/10.1080/02673843.2020.1828111

Adhikari, N., Adhikari, S., \& Sulemane, N. I. (2018). Premarital sexual behaviour among higher secondary students in Pokhara Sub-Metropolitan City Nepal. Sexual Health. https://doi.org/10.1071/SH17210

Agustiani, H. (2006). Psikologi Perkembangan: Pendekatan Ekologi Kaitannya dengan Konsep Diri dan Penyesuaian Diri pada Remaja. PT. Refika Aditama.

Ajzen, I., Fishbein, M., Lohmann, S., \& Albarracin, D. (2019). The Influence Attitude on Behavior. In \& D. A. B. T. Johnson (Ed.), Handbook of Attitudes (1st ed., pp. 197-255). Routledge. Ajzen, I. 
(1991). The theory of planned behavior. Organizational Behavior and Human Decision Processes. https://doi.org/10.1016/0749-5978(91)90020-T

Ajzen, I. (2005). Attitude, Personality, and Behavior. Open University Press.

Ajzen, I. (2019). Theory of Planned Behavior with Background Factors. https://people.umass.edu/aizen/tpb.background.html

Akers, A. Y., Cohen, E. D., Marshal, M. P., Roebuck, G., Yu, L., \& Hipwell, A. E. (2016). Objective and perceived weight: Associations with risky adolescent sexual behavior. Perspectives on Sexual and Reproductive Health. https://doi.org/10.1363/48e11416

Amoateng, A. Y., \& Kalule-Sabiti, I. (2016). Biosocial correlates of age at first sexual intercourse: the case of grade 9 and grade 11 pupils in The North West Province of South Africa. Journal of Biosocial Science. https://doi.org/10.1017/S0021932014000492

AS, M., M, de L., P, M., CT, H., T, F., TF, T. B., V, E., S, N. G., C, C., \& E, G. (2014). Macro-level age norms for the timing of sexual initiation and adolescents' early sexual initiation in 17 European countries. The Journal of Adolescent Health: Official Publication of the Society for Adolescent Medicine, 55(1), 114-121. https://doi.org/10.1016/J.JADOHEALTH.2013.12.008

Awaluddin, S. M., Ahmad, N. A., Mohd. Saleh, N., Aris, T., Mohd Kasim, N., Muhammad Sapri, N. A., \& Nik Abdul Rashid, N. R. (2015). Prevalence of sexual activity in older Malaysian adolescents and associated factors. Journal of Public Health Aspects. https://doi.org/10.7243/2055-7205-2-1

Bauer, S. (2015). The association of sociodemographic, behavioural and informational factors with engaging in sexual intercourse among never-married adolescents aged 15-24 years in Indonesia: A secondary analysis of DHS data from 2012. Uppsala Universitet.

Bengesai, A. V., Khan, H. T. A., \& Dube, R. (2018). Effect of early sexual debut on high school completion in South Africa. Journal of Biosocial Science. https://doi.org/10.1017/S0021932017000104

Berliana, S. M., Utami, E. D., Efendi, F., \& Kurniati, A. (2018). Premarital sex initiation and the time interval to first marriage among Indonesians. Bulletin of Indonesian Economic Studies. https://doi.org/10.1080/00074918.2018.1440067

Bleakley, A., Hennessy, M., Fishbein, M., \& Jordan, A. (2009). How sources of sexual information relate to adolescents' beliefs about sex. American Journal of Health Behavior, 33(1), 37. $/ \mathrm{pmc} /$ articles/PMC2860278/

BPS Kota Medan. (2020). Kota Medan Dalam Angka. In Katalog BPS: 1102001.1275 (p. 563 ). Biro Pusat Statistik Kota Medan. https://medankota.bps.go.id/publication/download.html?nrbvfeve=NGQ4ODExNDA4NWU1OTh hYmF1MjNjM2U1\&xzmn=aHR0cHM6Ly9tZWRhbmtvdGEuYnBzLmdvLmlkL3B1YmxpY2F0a W9uLzIwMjAvMDUvMjAvNGQ4ODExNDA4NWU1OThhYmF1MjNjM2U1L2tvdGEtbWVkY W4tZGFsYW0tYW5na2EtMjAyMC5odG1s\&twoadfnoa

Cueto, S., \& Leon, J. (2016). Early sexual initiation among adolescents: A longitudinal analysis for 15year-olds in Peru. Interamerican Journal of Psychology. https://doi.org/10.30849/rip/ijp.v50i2.2

Dinamika Rakyat. (2017). Tujuh Mucikari Ditangkap Polda Sumut. DR Berita. https://www.drberita.com/undercover/7-Mucikari-Ditangkap--Polda-Sumut-Akui-Kejahatan-Seksdi-Medan-Terus-Berevolusi

DKT Indonesia. (2019). Sexual Behaviour of Youth.

Donahue, K. L., Lichtenstein, P., Långström, N., \& D’Onofrio, B. M. (2013). Why does early sexual intercourse predict subsequent maladjustment? Exploring potential familial confounds. Health Psychology. https://doi.org/10.1037/a0028922

Doornwaard, S. M., Ter Bogt, T. F. M., Reitz, E., \& Van Den Eijnden, R. J. J. M. (2015). Sex-related online behaviors, perceived peer norms and adolescents' experience with sexual behavior: Testing an integrative model. PLOS ONE. https://doi.org/10.1371/journal.pone.0127787

Efendi, R. (2018). Bocah-Bocah Terciduk Saat Asyik Dugem di Diskotek Berkedok Toko Es Krim. Liputan 6. https://www.liputan6.com/regional/read/3618529/bocah-bocah-terciduk-saat-asyikdugem-di-diskotek-berkedok-toko-es-krim

Eisenberg, M. E., Madsen, N., Oliphant, J. A., \& Sieving, R. E. (2013). Barriers to providing the sexuality education that teachers believe students need. Journal of School Health. https://doi.org/10.1111/josh.12036 
Eversole, J. S., Berglas, N. F., Deardorff, J., \& Constantine, N. A. (2016). Source of Sex Information and Condom Use Intention Among Latino Adolescents. https://doi.org/10.1177/1090198116671704

Farid, N. D. N., Rus, S. C., Dahlui, M., Al-Sadat, N., \& Aziz, N. A. (2014). Predictors of sexual risk behaviour among adolescents from welfare institutions in Malaysia: A cross sectional study. BMC Public Health. https://doi.org/10.1186/1471-2458-14-S3-S9

Fatoni, Z., \& Situmorang, A. (2020). Determinan perilaku berisiko remaja terkait seksualitas di era globalisasi: Kasus Kota Medan. Jurnal Kependudukan Indonesia. https://doi.org/10.14203/jki.v14i2.491

Fortenberry, J. D. (2013). Hormones and behavior puberty and adolescent sexuality. Hormones and Behavior, 64(2), 280-287. https://doi.org/10.1016/j.yhbeh.2013.03.007

Fraselia Putri, A., Risma, D., \& Anggia Fraselia Putri, B. (2021). Faktor-faktor yang mempengaruhi seks pranikah pada remaja SMA di Rengat Kabupaten Indragiri Hulu. Laporan Penelitian: Universitas Riau

$\mathrm{Fu}, \mathrm{X}$., \& Juan, Z. (2017). Understanding public transit use behavior: integration of the theory of planned behavior and the customer satisfaction theory. Transportation. https://oi.org/10.1007/s11116016-9692-8

Goldberg, S. K., Haydon, A. A., Herring, A. H., \& Halpern, C. T. (2014). Longitudinal consistency in self-reported age of first vaginal intercourse among young adults. Journal of Sex Research. https://doi.org/10.1080/00224499.2012.719169

Gräf, D. D., Mesenburg, M. A., \& Fassa, A. G. (2020). Risky sexual behavior and associated factors in undergraduate students in a city in Southern Brazil. Revista de Saude Publica. https://doi.org/10.11606/S1518-8787.2020054001709

J.S., S., X., S., I.K., H., K., W., X., Z., Y., W., S., M., T., L., F., N., R.H., G., \& D.M., S. (2015). Prevalence of sexual experience and initiation of sexual intercourse among adolescents, Rakai District, Uganda, 1994-2011. Journal of Adolescent Health. https://doi.org/10.1016/j.jadohealth.2015.07.018

Khairani. (2020). Infodatin: Pusat Data dan Informasi Kemertrian Kesehtan RI. https://pusdatin.kemkes.go.id/resources/download/pusdatin/infodatin/infodatin-2020-HIV.pdf

Kinaro, J. W. (2013). Why adults and teachers information about sexual behavior and its consequences does not prevent unplanned pregnancies among adolescents in Nairobi, Kenya. Health. https://doi.org/10.4236/health.2013.51003

Lanari, D., Mangiavacchi, L., \& Pasqualini, M. (2020). Adolescent sexual behaviour and academic performance of Italian students. Genus. https://doi.org/10.1186/s41118-020-00093-4

Landry, M., Turner, M., Vyas, A., \& Wood, S. (2017). Social media and sexual behavior among adolescents: Is there a link? JMIR Public Health and Surveillance. https://doi.org/10.2196/publichealth.7149

Lara, L. A. S., \& Abdo, C. H. N. (2016). Age at time of initial sexual intercourse and health of adolescent girls. In Journal of Pediatric and Adolescent Gynecology. https://doi.org/10.1016/j.jpag.2015.11.012

Lee, J. E., \& Park, J. H. (2020). Effects of socialization on adolescent sexual behaviors in Lao PDR. Journal of Child and Family Studies. https://doi.org/10.1007/s10826-020-01713-5

LeJeune, B. C., Zimet, G. D., Azzouz, F., Dennis Fortenberry, J., \& Aalsma, M. C. (2013). Religiosity and sexual involvement within adolescent romantic couples. Journal of Religion and Health. https://doi.org/10.1007/s10943-011-9512-6

Lin, L. M., Tung, T. H., \& Yeh, M. Y. (2019). Examining determinants of sexual behavior among indigenous adolescents in Taiwan. Medicine. https://doi.org/10.1097/MD.0000000000015562

Lino, S., Marshak, H. H., Patti Herring, R., Belliard, J. C., Hilliard, C., Campbell, D., \& Montgomery, S. (2014). Using the theory of planned behavior to explore attitudes and beliefs about dietary supplements among HIV-positive Black women. In Complementary Therapies in Medicine. https://doi.org/10.1016/j.ctim.2014.03.002

Litras, A., Latreille, S., \& Temple-Smith, M. (2015). Dr Google, porn and friend-of-a-friend: Where are young men really getting their sexual health information? Sexual Health. https://doi.org/10.1071/SH15055

Lubis, R. (2018). Psikologi dan Pendidikan dalam Konteks Kebangsaan (T. Susanna, B. K. I. Graito, J. 
M. J. Ratna, J. Abraham, J. S. A. Utama, \& A. Supratiknya (Eds.); pp. 91-122). Himpunan Psikologi Indonesia.

Lubis, R., Hinduan, Z. R., Jatnika, R., \& Agustiani, H. (2020). An elicitation study on sexual salient belief in middle adolescents who engage in early sexual intercourse. Talent Development \& Excellence.

Lyons, Heidi A., Manning, W. D., Longmore, M. A., \& Giordano, P. C. (2015). Gender and casual sexual activity from adolescence to emerging adulthood: Social and life course correlates. Journal of Sex Research. https://doi.org/10.1080/00224499.2014.906032

Lyons, Heidi Ann. (2017). Heterosexual casual sex and sti diagnosis: A latent class analysis. International Journal of Sexual Health. https://doi.org/10.1080/19317611.2016.1210711

Madkour, A. S., Farhat, T., Halpern, C. T., Godeau, E., \& Nic Gabhainn, S. (2010). Early adolescent sexual initiation and physical/psychological symptoms: A comparative analysis of five nations. Journal of Youth and Adolescence. https://doi.org/10.1007/s10964-010-9521-x

Manaf, M. R. A., Tahir, M. M., Sidi, H., Midin, M., Jaafar, N. R. N., Das, S., \& Malek, A. M. A. (2014). Pre-marital sex and its predicting factors among Malaysian youths. Comprehensive Psychiatry. https://doi.org/10.1016/j.comppsych.2013.03.008

Marino, C., Vieno, A., Lenzi, M., \& Santinello, M. (2014). Time trends in adolescent sexual behaviour in Italy. Sexual Health. https://doi.org/10.1071/SH14094

Mekonen, M. T., Dagnew, H. A., Yimam, T. A., Yimam, H. N., \& Reta, M. A. (2018). Adolescentparent communication on sexual and reproductive health issues and associated factors among high school students in Woldia town, Northeastern Ethiopia. The Pan African Medical Journal. https://doi.org/10.11604/pamj.2018.31.35.13801

Mohammadi, M. A., Gharehghani, Khosravi, B., Irandoost, S. F., Soofizad, G., \& Lebni, J. Y. (2020). Barriers to condom use among female sex workers in tehran, iran: A qualitative study. International Journal of Women's Health. https://doi.org/10.2147/IJWH.S260481

National AIDS Commission Secretary. (2012). National HIV and AIDS Strategy and Action Plan 20102014. Nac.

Nigussie, T., Legese, T., Abebe, L., Getachew, S., \& Alemayehu, D. (2020). Magnitude of risky sexual behaviors, determinants, and consequences among high school and preparatory school students in Mizan Aman Town, Ethiopia. Journal of Midwifery \& Reproductive Health.

Nogueira Avelar e Silva, R., Raat, H., Reitz, E., Plat, M., Deković, M., \& Van De Bongardt, D. (2020). Longitudinal associations between sexual communication with friends and sexual behaviors through perceived sexual peer norms. Journal of Sex Research. https://doi.org/10.1080/00224499.2019.1691969

O'Sullivan, L. F. (2015). High texting rates mediate oral sex and intercourse experience in a longitudinal study of high school students. Computers in Human Behavior. https://doi.org/10.1016/j.chb.2015.03.049

Okigbo, C. C., Kabiru, C. W., Mumah, J. N., Mojola, S. A., \& Beguy, D. (2015). Influence of parental factors on adolescents' transition to first sexual intercourse in Nairobi, Kenya: A longitudinal study. Reproductive Health. https://doi.org/10.1186/s12978-015-0069-9

Oktriyanto, O., \& Alfiasari, A. (2019). Dating and premarital sexual inisiation on adolescence in Indonesia. Jurnal Kesehatan Masyarakat. https://doi.org/10.15294/kemas.v15i1.17270

Olaoye, T., \& Agbede, C. (2019). Prevalence and personal predictors of risky sexual behaviour among in-school adolescents in the Ikenne Local Government Area, Ogun State, Nigeria. International Journal of Adolescent Medicine and Health. https://doi.org/10.1515/ijamh-2019-0135

Oudekerk, B. A., Guarnera, L. A., \& Reppucci, N. D. (2014). Older opposite-sex romantic partners, sexual risk, and victimization in adolescence. Child Abuse and Neglect. https://doi.org/10.1016/j.chiabu.2014.03.009

Overbeek, G., van de Bongardt, D., \& Baams, L. (2018). Buffer or brake? The role of sexuality-specific parenting in adolescents' sexualized media consumption and sexual development. Journal of Youth and Adolescence. https://doi.org/10.1007/s10964-018-0828-3

Pariera, K. L. (2018). Women's sexual communication with their peers and its association with sexual wellbeing. International Journal of Sexual Health. https://doi.org/10.1080/19317611.2018.1491923 
Parkes, A., Wight, D., Hunt, K., Henderson, M., \& Sargent, J. (2013). Are sexual media exposure, parental restrictions on media use and co-viewing TV and DVDs with parents and friends associated with teenagers' early sexual behaviour? Journal of Adolescence, 36(6), 1121-1133. https://doi.org/10.1016/j.adolescence.2013.08.019

Patui, N. S., Dasuki, D., \& Wahyuni, B. (2018). The roles of parents and peer friends on adolescent premarital sex behavior in high school students of Buol District. Jurnal Kesehatan Reproduksi. https://doi.org/10.22146/jkr.37995

Peltzer, K., \& Pengpid, S. (2016). Risk and protective factors affecting sexual risk behavior among school-aged adolescents. https://doi.org/10.1177/1010539516650725

Pikunas, J., Albrecht, E. J., Pikunas, J., \& Albrecht, E. J. (2014). Puberal Developments. In Psychology of Human Development. https://doi.org/10.1037/14382-014

Poudel, K. C., Poudel-Tandukar, K., Nakahara, S., Yasuoka, J., \& Jimba, M. (2011). Knowing the consequences of unprotected sex with seroconcordant partner is associated with increased safer sex intentions among HIV-positive men in Kathmandu, Nepal. Journal of Health, Population and Nutrition. https://doi.org/10.3329/jhpn.v29i3.7866

Prendergast, L. E., Toumbourou, J. W., McMorris, B. J., \& Catalano, R. F. (2019). Outcomes of early adolescent sexual behavior in Australia: Longitudinal findings in young adulthood. Journal of Adolescent Health. https://doi.org/10.1016/j.jadohealth.2018.10.006

Rahmartani, L. D., \& Adisasmita, A. (2019). Association between knowledge of condom functions and condom use among sexually-active unmarried male adolescents in Indonesia. Jurnal Epidemiologi Kesehatan Indonesia. https://doi.org/10.7454/epidkes.v2i2.3131

Rigo, C., \& Saroglou, V. (2018). Religiosity and sexual behavior: Tense relationships and underlying affects and cognitions in samples of christian and muslim traditions. Archive for the Psychology of Religion. https://doi.org/10.1163/15736121-12341359

Rothman, E. F., Kaczmarsky, C., Burke, N., Jansen, E., \& Baughman, A. (2015). Without porn. I wouldn't know half the things I know now": A Qualitative Study of Pornography Use among a Sample of Urban, Low-Income, Black and Hispanic Youth. Journal of Sex Research. https://doi.org/10.1080/00224499.2014.960908

Salih, N. A., Metaferia, H., Reda, A. A., \& Biadgilign, S. (2015). Premarital sexual activity among unmarried adolescents in northern Ethiopia: A cross-sectional study. Sexual and Reproductive Healthcare. https://doi.org/10.1016/j.srhc.2014.06.004

Santelli, J. S., X., S., I.K., H., K., W., X., Z., Y., W., S., M., T., L., F., N., R.H., G., \& D.M., S. (2015). Prevalence of sexual experience and initiation of sexual intercourse among adolescents, Rakai District, Uganda, 1994-2011. Journal of Adolescent Health. https://doi.org/10.1016/j.jadohealth.2015.07.018

Sanusi, S. R., \& Arde M., L. D. (2019). Efektifitas metode pengukuran perilaku seksual remaja usia 1521 tahun berdasarkan teknik self administered dan interview-based questioner. Jurnal Kesehatan. https://doi.org/10.26630/jk.v10i3.1212

Sari, D. E., \& Rokhanawati, D. (2018). The correlation between age of first dating and sexual behavior of adolescents and young adults in indonesia. Journal of Health Technology Assessment in Midwifery. https://doi.org/10.31101/jhtam.441

Senn, T. E., \& Carey, M. P. (2011). Age of partner at first adolescent intercourse and adult sexual risk behavior among women. Journal of Women's Health, 20(1), 61. https://doi.org/10.1089/JWH.2010.2089

Shek, D. T. L. (2013). Sexual behavior and intention to engage in sexual behavior in junior secondary school students in Hong Kong. Journal of Pediatric and Adolescent Gynecology. https://doi.org/10.1016/j.jpag.2013.03.013

Socio-cultural and socio-sexual factors influence the premarital sexual behaviour of Javanese youth in the era of HIV/AIDS. (2007). Jurnal Promosi Kesehatan Indonesia. https://doi.org/10.14710/jpki.2.2.61-72

Soler-Hampejsek, E., Grant, M. J., Mensch, B. S., Hewett, P. C., \& Rankin, J. (2013). The effect of school status and academic skills on the reporting of premarital sexual behavior: Evidence from a longitudinal study in rural Malawi. Journal of Adolescent Health. https://doi.org/10.1016/j.jadohealth.2013.03.008 
Steinberg, L. (2002). Adolescence. Mc. Graw Hill. Inc. Co.

Suleiman, A. B., \& Deardorff, J. (2015). Multiple dimensions of peer influence in adolescent romantic and sexual relationships: A descriptive, qualitative perspective. Archives of Sexual Behavior. https://doi.org/10.1007/s10508-014-0394-z

Susanto, T., Rahmawati, I., Wuryaningsih, E. W., Saito, R., Syahrul, Kimura, R., Tsuda, A., Tabuchi, N., \& Sugama, J. (2016). Prevalence of factors related to active reproductive health behavior: a crosssectional study Indonesian adolescent. Epidemiology and Health. https://doi.org/10.4178/epih.e2016041

Sylviana, E., Sanusi, S. R., \& Tukiman, T. (2018). The Association between Exposure to Pornography and Sexual Behavior in Adolescents in Medan, North Sumatera. https://doi.org/10.26911/mid.icph.2018.02.15

Tolou-Shams, M., Brogan, L., Esposito-Smythers, C., Healy, M. G., Lowery, A., Craker, L., \& Brown, L. K. (2018). The role of family functioning in parenting practices of court-involved youth. Journal of Adolescence. https://doi.org/10.1016/j.adolescence.2017.12.016

Turchik, J. A. (2011). The prediction of sexual risk behaviors among college students using the theory of planned behavior. In Dissertation Abstracts International: Section B: The Sciences and Engineering.

Walsh, J. L., Ward, L. M., Caruthers, A., \& Merriwether, A. (2010). Awkward or amazing: Gender and age trends in first intercourse experiences. Psychology of Women Quarterly. https://doi.org/10.1177/0361684310387781

Wanufika, I., Sumarni, S., \& Ismail, D. (2017). Komunikasi orang tua tentang seksualitas terhadap perilaku seksual pranikah pada remaja. Berita Kedokteran Masyarakat. https://doi.org/10.22146/bkm.26079

Wong, L. P. (2012). Qualitative inquiry into premarital sexual behaviours and contraceptive use among multiethnic young women: Implications for education and future research. PLOS ONE, 7(12), e51745. https://doi.org/10.1371/JOURNAL.PONE.0051745

Yaya, S., \& Bishwajit, G. (2018). Age at first sexual intercourse and multiple sexual partnerships among women in Nigeria: A Cross-Sectional Analysis. Frontiers in Medicine, 5(JUN), 171. https://doi.org/10.3389/FMED.2018.00171

Zou, S., Cao, W., Jia, Y., Wang, Z., Qi, X., Shen, J., \& Tang, K. (2021). Sexual and reproductive health and attitudes towards sex of young adults in China. BMJ Sexual \& Reproductive Health. https://doi.org/10.1136/bmjsrh-2020-200766 